\title{
Primary Lymphoma of the Pericardium
}

\author{
Shintaro Kinoshita ${ }^{1}$, Jun Ando ${ }^{1,2}$, Miki Ando ${ }^{1}$ and Norio Komatsu ${ }^{1}$
}

Key words: pericardium, primary cardiac lymphoma, right heart failure

(Intern Med Advance Publication)

(DOI: 10.2169/internalmedicine.7643-21)
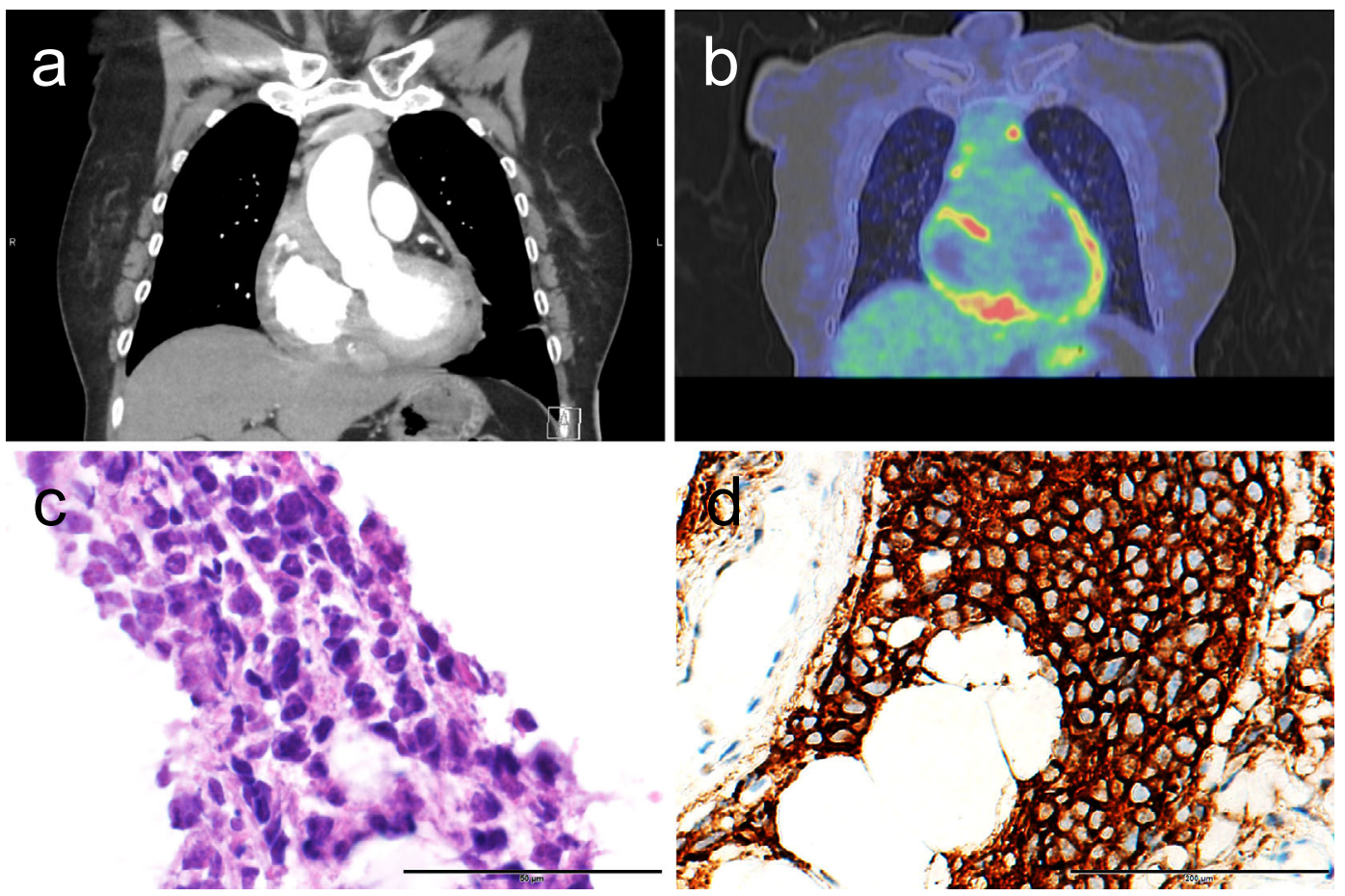

Picture.

An 81-year-old woman was admitted for right heart failure with complete atrioventricular block. Chest computed tomography (CT) revealed disseminated nodular lesions of the pericardium (Picture a), and positron emission tomographyCT revealed an uptake only along the pericardium (Picture b), with a maximal standardized uptake value of 9.56 . A pericardial biopsy showed infiltration by intermediatesized to large atypical lymphocytes expressing the B-cell marker CD20 (Picture c, d). Diffuse large B-cell lymphoma, not otherwise specified (WHO 2016 classification) was diagnosed. Vincristine and prednisolone were initiated for cytoreduction before rituximab treatment, and her condition temporarily improved, but sepsis occurred, and the patient died of multi-organ failure. Primary cardiac lymphoma is extremely rare, accounting for only $0.15 \%$ of all nonHodgkin lymphomas. For only pericardial disease to be demonstrable is even rarer $(0.05 \%)(1,2)$. In patients like ours, malignancy should always be considered. Our experience underscores the importance of a pericardial biopsy for a definitive diagnosis.

The authors state that they have no Conflict of Interest (COI).

\section{References}

1. Jeudy J, Burke AP, Frazier AA. Cardiac Lymphoma. Radiol Clin

${ }^{1}$ Department of Hematology, Juntendo University School of Medicine, Japan and ${ }^{2}$ Department of Transfusion Medicine and Stem Cell Regulation, Juntendo University School of Medicine, Japan

Received: April 3, 2021; Accepted: April 25, 2021; Advance Publication by J-STAGE: June 12, 2021

Correspondence to Dr. Miki Ando, m-ando@juntendo.ac.jp 
North Am 54: 689-710, 2016.

2. Jonavicius K, Salcius K, Meskauskas R, Valeviciene N, Tarutis V, Sirvydis V. Primary cardiac lymphoma: two cases and a review of literature. J Cardiothorac Surg 10: 138, 2015.
The Internal Medicine is an Open Access journal distributed under the Creative Commons Attribution-NonCommercial-NoDerivatives 4.0 International License. To view the details of this license, please visit (https://creativecommons.org/licenses/ by-nc-nd/4.0/).

(C) The Japanese Society of Internal Medicine

Intern Med Advance Publication 